\title{
Mix Design of Self Compacting Concrete Based on Ultra High Compressive Strength Flow Mortar Mix
}

\author{
Soca Anggoro Wulan \\ Highway and Water Resource Office, Tangerang, INDONESIA \\ Soca.anggoro@gmail.com \\ Iman Satyarno \\ Department of Civil and Environment Engineering, Universitas Gadjah Mada, Yogyakarta, INDONESIA \\ imansatyarno@ugm.ac.id \\ Ashar Saputra \\ Department of Civil and Environment Engineering, Universitas Gadjah Mada, Yogyakarta, INDONESIA \\ saputra@ugm.ac.id
}

\begin{abstract}
Mix design for Self Compacting Concrete or SCC cannot be conducted directly because there are many control parameters in its rheological properties. This case becomes more complex if it should achieve a high compressive strength. The following is the simple approach that can be used, firstly, determining the flow of mortar mix which was designed based on the high strength determination. The mix design of SCC is then determined by adding the coarse aggregate in the mortar mix. In this research, the design of mix mortar flow with ultra-high compressive strength was made by the type I cement, i.e. $15 \%$ of cement weight silica fume with the ratio of the cement and the fine aggregate was $1: 0.35$, the fine aggregates was on the VI graded and the superplasticizer content was $1.3 \%, 1.4 \%, 1.5 \%$ and $1.6 \%$. In case of the SCC, the coefficient was taken on 1.4, 1.6, and 1.8 from the volume of void aggregate, the coarse aggregate value was using the remaining volume of absolute mortar on one cubic meter concrete with the size of $4.8 \mathrm{~mm}-9.6 \mathrm{~mm}$. Test results showed that the mortar flowability was $170 \mathrm{~mm}$, $180 \mathrm{~mm}, 220 \mathrm{~mm}$ and $250 \mathrm{~mm}$ with the compressive strength was 83.1 MPa, 96.8 MPa, 111.4 MPa, and 135.5 MPa respectively. Mortar mix with $1.6 \%$ superplasticizer was then used for making the SCC and the results showed that the concrete flow was $460 \mathrm{~mm}, 580 \mathrm{~mm}$ and $660 \mathrm{~mm}$ while the compressive strength was $88.2 \mathrm{MPa}, 100.0 \mathrm{MPa}$, and 97.9 MPa. Therefore, it can be concluded that by using this approach, SCC can have $580 \mathrm{~mm}$ of flow and $100 \mathrm{MPa}$ for compressive strength.
\end{abstract}

Keywords: flow, mortar, concrete, self-compacting, compressive strength

\section{INTRODUCTION}

The rapid development of infrastructure should be supported by the effectiveness and efficiency use of energy and materials because the punctuality aspect is really urgent in the building process. So, the precast technology plays a very important role here. Highquality building materials are beneficial to building performance and physical infrastructure. Currently, building materials are required to be energy efficient, environmentally friendly, sustainable and resilient (Fehling \& Schmidt, 2010).

The building materials are demanded to meet the load requirements, design criteria, ease of production \& application. One of the current concrete technologies that are often used to support precast materials is SCC or self-compacted concrete. SCC applications can compact by itself by utilizing its weight and flow without the compaction process. In SCC concrete, the mortar should fulfill the flowability. Mortar and SCC with high workability will be very complex if the high compressive strength should also be achieved.

This study aimed at finding a mixture of concrete that has high performance in both condition of wet and solid. The mortar mix is designed with pre-set designs in the laboratory. The addition of superplasticizer on the mixture is to achieve its physical and mechanical properties such as mortar has a flow value, and SCC has the flowability, passability, and viscosity that has been set in EFNARC 2005.

SCC can be categorized as high-performance concrete and with the proper material selection and design plan, it is also possible to have relatively high compressive strength. High-Performance Concrete was H.S.C with compressive strength $450-700 \mathrm{MPa}$ and U.H.S.C 700 - $1000 \mathrm{MPa}$ (Raju, 1983). UHPC not only offers superior compressive strength, but also 
extraordinary ductility and far more durability than ordinary concrete. It enables to build structures which are sustainable and economical and come to light on filigree appears at the same time (Fehling \& Schmidt, 2010). High-Performance Concrete has compressive strength $60 \mathrm{MPa}$ to $100 \mathrm{MPa}$, and construct from lightweight additive materials, cement Portland $400-$ $450 \mathrm{~kg} / \mathrm{m}^{3}$, used chemical additive is like high range water reducer (HRWR), w/c $0.35-0.4$ without affecting the workability (Okamura \& Ouchi, 2003). Meanwhile, Self-Compacting Concrete (SCC) was a concrete can compact with own weight without vibration, and can flow into the entire mold (EFNARC, 2005).

\section{MATERIAL AND METHODS}

The material used in this research consists of OPC type I cement, silica fume by SIKA, fine aggregate, coarse aggregate, and chemical add mixture by SIKA, i.e. Viscocrete 1003. Those were local materials that can be easily found around Yogyakarta. The main equipment was a mortar mixer, a flow cone apparatus, $50 \mathrm{~mm}$ cube mortar mold, concrete mixer, cylinder $100 \mathrm{~mm}$ diameters concrete mold, a compressive test machine of Avery-Denison with a capacity of $200 \mathrm{kN}$. The materials characteristics are presented in Table 1.

Table 1. Property of material

\begin{tabular}{cccc}
\hline Characteristic & $\begin{array}{c}\text { Fine } \\
\text { Aggregate }\end{array}$ & $\begin{array}{c}\text { Coarse } \\
\text { Aggregate }\end{array}$ & $\begin{array}{c}\text { Silica } \\
\text { Fume }\end{array}$ \\
\hline Specific & 2.81 & 2.53 & 2.2 \\
Gravity & 1604.06 & 1287.92 & $600 \mathrm{~kg} / \mathrm{m}^{3}$ \\
Unit weight & $\mathrm{kg} / \mathrm{m}^{3}$ & $\mathrm{~kg} / \mathrm{m}^{3}$ & - \\
Void volume & - & $50 \%$ & - \\
Abrasion & - & 22.5 & - \\
Rudeloff & - & $16 \%$ & \\
\hline
\end{tabular}

The sand gradation is normally divided into gradation of IV zones (BSNI, 2000) as shown in Table 2. The gradation graphics can be seen in Figure 1.

Table 2. Sand gradation category

\begin{tabular}{cccc}
\hline $\begin{array}{c}\text { Sieve } \\
\text { size } \\
(\mathrm{mm})\end{array}$ & $\begin{array}{c}\text { Percentage } \\
\text { Passing }\end{array}$ & $\begin{array}{c}\text { Percentage } \\
\text { cumulative } \\
\text { Passing }\end{array}$ & $\begin{array}{c}\text { Percentage } \\
\text { weight }\end{array}$ \\
\hline 4.8 & $95-100$ & 100 & 0 \\
2.4 & $95-100$ & 100 & 0 \\
1.2 & $90-100$ & 95 & 5 \\
0.6 & $80-100$ & 90 & 5 \\
0.3 & $15-50$ & 32.5 & 57.5 \\
0.15 & $0-15$ & 7.5 & 25 \\
0.075 & Pan & 0 & 7.5 \\
\hline
\end{tabular}

Mortar be measured its flowability by using a small cone test which is tailored to EFNARC 2005.
Variations of superplasticizer dosing were added to the mortar until the diameter flow range of $240-260$ mm (EFNARC, 2005).

\subsection{Mix Design of Mortar and Concrete}

The mix design of mortar calculated using the absolute volume of each material such as water, cement, fine aggregate, silica fume and superplasticizer.

$\frac{W_{w}}{G_{w} \times \gamma_{w}}+\frac{W_{c}}{G_{c} \times \gamma_{w}}+\frac{W_{f . a}}{G_{f . a} \times \gamma_{w}}+\frac{W_{s f}}{G_{s f} x \gamma_{w}}+\frac{W_{s p}}{G_{s p} \times \gamma_{w}}=1$

Using water-cementitious materials ratio of $0.22,15 \%$ of silica fume by cement weight, the cement and sand ratio was $1: 0.35$, and variation of superplasticizer dosage was $1.3 \%-1.6 \%$. The calculation below was the sample of variation dosage of superplasticizer $1.3 \%$.

$W_{w}=\left(0.22 W_{c}\right)+\left(0.22 W_{s f}\right)$

$W_{c}=W_{c}$

$W_{f . a}=0.35 W_{c}$

$W_{s f}=15 \% W_{c}$

$W_{s p}=1.3 \% W_{c}$

Based on the calculation above, it means that if the weight of cement was known, the weight of each material can be calculated.

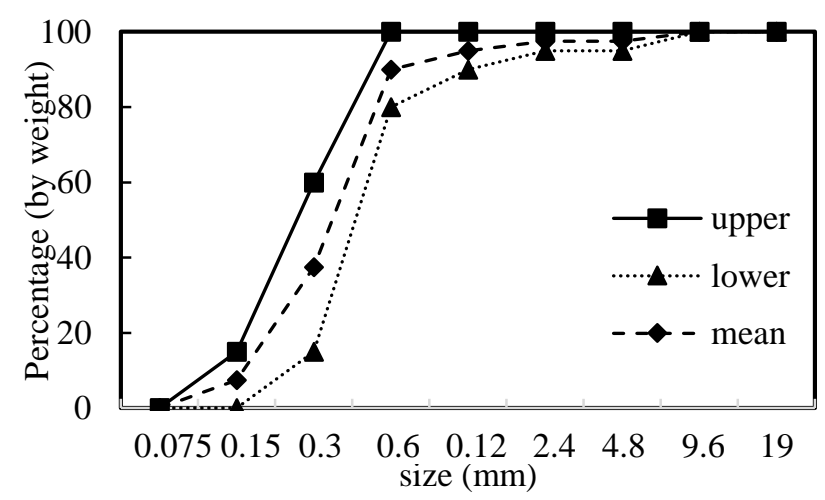

Figure 1. Sand gradation zone IV based on average percentage passing.

After mortar calculations are known, the amount of mortar composite material in one cubic meter of concrete can be calculated by multiplying the percent of the aggregate air content and the absolute-mortar volume coefficient by the absolute volume of the material on the mortar mixture. Meanwhile, coarse aggregate is the residual value of one cubic meter of 
concrete minus the absolute volume amount of mortar composing material in one cubic meter of concrete.

$W_{\text {concrete }}=W_{\text {mortar }} x V_{\text {void }} x C_{\text {oef }}$

$1-\frac{W_{w}}{G_{w} x \gamma_{w}}+\frac{W_{c}}{G_{c} x \gamma_{w}}+\frac{W_{f . a}}{G_{f . a} x \gamma_{w}}+\frac{W_{s f}}{G_{s f} x \gamma_{w}}+\frac{W_{s p}}{G_{s p} x \gamma_{w}}=\frac{W_{c . a}}{G_{c . a} \times \gamma_{w}}$

where:

$W_{w} \quad:$ The need of water weight per cubic meter,

$W_{c} \quad:$ The need of cement weight per cubic meter

$W_{f a} \quad:$ The need of fine aggregate per cubic meter,

$W_{s f} \quad:$ The need of silica fume per cubic meter,

$W_{s p} \quad:$ The need of superplasticizer per cubic meter,

$W_{\text {c.a }} \quad:$ The need of course aggregates per cubic meter,

$G_{W} \quad:$ Specific gravity of water,

$G_{c} \quad:$ Specific gravity of cement,

$G_{f a} \quad:$ Specific gravity of fine aggregate,

$G_{S f} \quad:$ Specific gravity of silica fume,

$G_{s p} \quad:$ Specific gravity of superplasticizer,

$G_{c . a} \quad:$ Specific gravity, of coarse aggregate,

$\gamma_{w} \quad:$ Unit weight of water,

$W_{\text {concrete }}:$ The need of material of mortar per cubic the meter of concrete,

$W_{\text {mortar }}:$ The need of material per cubic meter of mortar,

$V_{v} \quad:$ Aggregate void volume per cubic meter,

$C_{\text {oef }} \quad:$ Coefficient volume of mortar per cubic meter,

$f_{m}^{\prime} \quad$ : Compressive strength of mortar,

$f^{\prime}{ }_{c} \quad$ : Compressive strength of concrete.

\subsection{Methods}

This research did not use the water-cementitious ratio below w/c 0.22 in order to optimize of hydration since because the use of small w/c values can result in an imperfect hydration process (Maten, 2011). The lower use of the w/c value is to obtain the flow performance that mortar should be reduced (Satyarno, 2014). The use of $15 \%$ silica fume can give higher compressive strength and its strength will not increase after 90 days. (Mazloom, et al., 2004). Mortar, firstly, tested on the mini flow table and mortar molding with specimen size $50 \mathrm{~mm} \times 50 \mathrm{~mm}$ and the test for compressive strength in 28 days. The result of mortar design with the highest compressive strength score will be used for SCC making. SCC will be studied with the variation of absolute volume coefficient value of 1.4, 1.5 and 1.6 mortar. The fresh SCC was tested based on the requirement of EFNARC 2005, and it will be tested for compressive strength at 28 days with $100 \mathrm{~mm}$ and $200 \mathrm{~mm}$ diameter cylindrical test specimens.

\section{RESULT AND DISCUSSION}

\subsection{Mix Design}

Based on the calculation and material selection, the composition mixture of mortar and concrete can be seen in Table 3 and Table 4.

Table 3. Mortar composition per meter cubic

\begin{tabular}{llllll}
\hline \multirow{2}{*}{ Code } & & $\begin{array}{l}\text { M022 } \\
\text { SP1.3 }\end{array}$ & $\begin{array}{l}\text { M022S } \\
\text { P1.4 }\end{array}$ & $\begin{array}{l}\text { M022S } \\
\text { P1.5 }\end{array}$ & $\begin{array}{l}\text { M022S } \\
\text { P1.6 }\end{array}$ \\
\hline SP & $\%$ & $1.3 \%$ & $1.4 \%$ & $1.5 \%$ & $1.6 \%$ \\
w/c & & 0.22 & 0.22 & 0.22 & 0.22 \\
Cement & $\mathrm{kg}$ & 1289.8 & 1288.3 & 1286.7 & 1285.2 \\
Water & $\mathrm{kg}$ & 326.3 & 325.9 & 325.5 & 325.2 \\
FA & $\mathrm{kg}$ & 451.4 & 450.9 & 450.3 & 449.8 \\
$\mathrm{SF}$ & $\mathrm{kg}$ & 193.4 & 193.2 & 193.0 & 192.7 \\
$\mathrm{SP}$ & $\mathrm{kg}$ & 16.7 & 18.0 & 19.3 & 20.5 \\
\hline
\end{tabular}

Table 4. Concrete mix design

\begin{tabular}{lllll}
\hline Code & & B022C1.4 & B022C1.6 & B022C1.8 \\
\hline Coefficient & & 1.4 & 1.6 & 1.8 \\
w/c & & 0.22 & 0.22 & 0.22 \\
Cement & $\mathrm{kg}$ & 899.6 & 1028.1 & 1156.6 \\
Water & $\mathrm{Kg}$ & 277.6 & 260.1 & 292.6 \\
FA & $\mathrm{kg}$ & 314.8 & 359.8 & 404.8 \\
CA & $\mathrm{kg}$ & 734.5 & 481.2 & 227.9 \\
SF & $\mathrm{kg}$ & 134.9 & 154.2 & 173.5 \\
SP & $\mathrm{kg}$ & 14.3 & 16.4 & 18.5 \\
\hline
\end{tabular}

3.2 Flow Mortars and Compressive Strength

The increasing of superplasticizer causes the flowability of mortars as shown in Figure 2. The addition of superplasticizer can increase the flow rate of mortar. The maximum flow capability was at 250 $\mathrm{mm}-300 \mathrm{~mm}$ with time on the mini $\mathrm{v}$-funnel test under 20 seconds. (Rahul \& Pardeep, 2013). This research used $15 \%$ silica fume and w/p 0.65, and superplasticizer $1.6 \%$ and $\mathrm{w} / \mathrm{p}$ comparison of 0.65 .

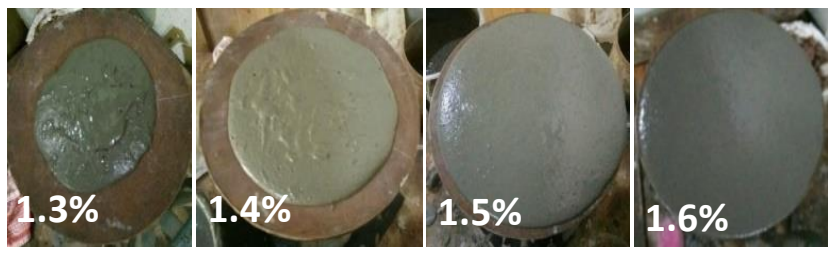

Figure 2. Influence of Super Plasticizer on the mortar mixture: (a) $1.3 \%$, (b) $1.4 \%$, (c) $1.5 \%$ and (d). $1.6 \%$.

Maximum compressive strength in w/c $0.22,15 \%$ of silica fume addition and $1.6 \%$ superplasticizer was 
135.45 MPa. It is in line with the research with w/c 0.22 and $16 \%$ silica fume addition and $2.5 \%$ dose of superplasticizer result in the highest compressive strength (Houssan \& Toutanji, 1995). Increasing the value of superplasticizer did not give direct effect on compressive strength. Mortar with flowing ability wars closely related to decreased air content in the test specimen, where an increase in the mortar flow value provides less air content (Tue, et al., 2008). The compressive strength of mortar can be seen in Table 5 and the relationship of superplasticizer addition to flowability and mortar compressive strength can be seen in Figure 3.

Table 5. Compressive strength of mortar

\begin{tabular}{llll}
\hline Specimen & SP $(\%)$ & Flow $(\mathrm{mm})$ & $f^{;}{ }_{m}(\mathrm{MPa})$ \\
\cline { 1 - 2 } M022SP1.3 & 1.3 & 170 & 83.09 \\
M022SP14 & 1.4 & 180 & 96.78 \\
M022SP1.5 & 1.5 & 220 & 111.37 \\
M022SP1.6 & 1.6 & 250 & 135.5 \\
\hline
\end{tabular}

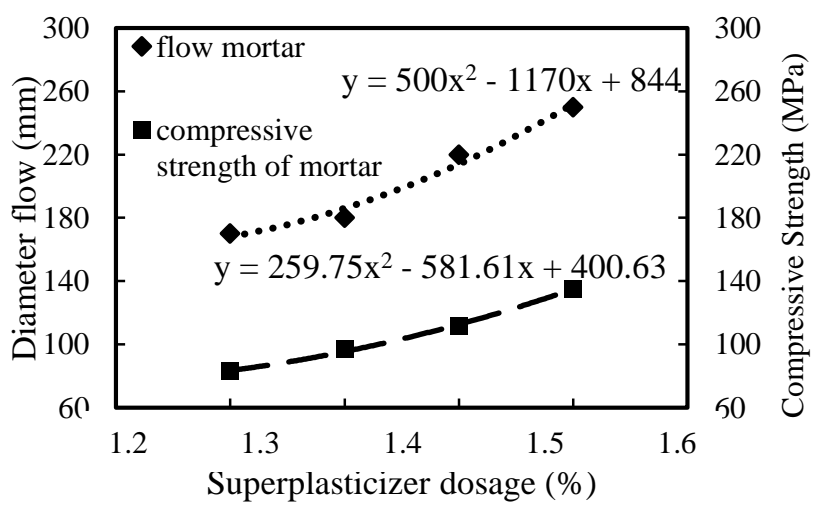

Figure 3. Flow and compressive strength of mortar.

\subsection{Concrete Rheology and Mechanics Properties}

The ability of flow in concrete increases along with the absolute volume coefficient of mortar which can be seen in Figure 4. Using the superplasticizer dose of $1.6 \%$ from the cement weight on SCC mix, the decrease of coarse aggregate gave significant influence to SCC rheology ability, as listed in Table 6.

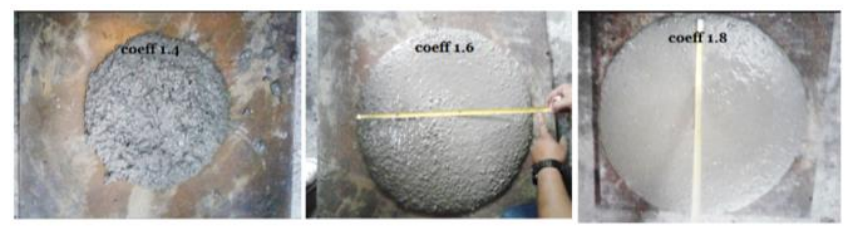

Figure 4. Concrete Flow in a variation of coefficient mortar absolute volume.

The correlation of compressive strength and the coefficient volume of absolute mortar can be seen in Figure 5. Meanwhile in Figure 6, air void appeared more in the coefficient of 1.4. The assertion that the highest SCC compressive strength is obtained on a ratio of roughly the same amount of coarse aggregate and fine aggregate (Widodo, 2004). The compressive strength of concrete increase with the addition of pasta to the concrete mixture to a certain point, after reaching a certain point the compressive strength tends to decrease (Yurdakul, 2013).

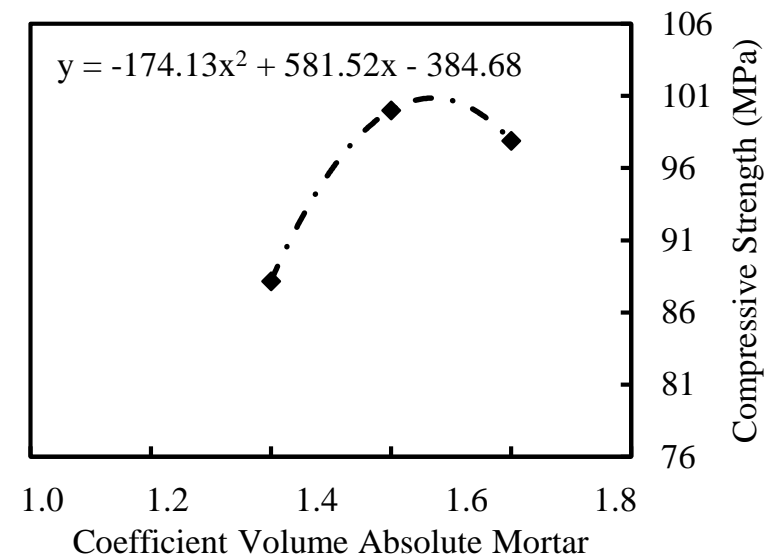

Figure 5. The compressive strength of concrete.

Table 6. Rheology of concrete

\begin{tabular}{|c|c|c|c|c|}
\hline Code & Ability & Test & EFNARC & Actual \\
\hline \multirow{4}{*}{$\begin{array}{l}\text { B022 } \\
\text { R1.4 }\end{array}$} & $\begin{array}{l}\text { Passign } \\
\text { ability }\end{array}$ & U-type & $0-30 \mathrm{~mm}$ & 100 \\
\hline & Viscosity & V-funnel & $\begin{array}{l}6-12 \\
\text { second }\end{array}$ & 20 \\
\hline & \multirow{2}{*}{$\begin{array}{l}\text { Filling } \\
\text { ability }\end{array}$} & $\begin{array}{l}\text { Slump } \\
\text { Flow }\end{array}$ & $\begin{array}{l}520-800 \\
\mathrm{~mm}\end{array}$ & 460 \\
\hline & & flow t-50 & $\begin{array}{l}2-5 \\
\text { second }\end{array}$ & 7 \\
\hline \multirow{4}{*}{$\begin{array}{l}\text { B022 } \\
\text { R1.6 }\end{array}$} & $\begin{array}{l}\text { Passign } \\
\text { ability }\end{array}$ & U-type & $0-30 \mathrm{~mm}$ & 45 \\
\hline & Viscosity & V-funnel & $\begin{array}{l}6-12 \\
\text { second }\end{array}$ & 17 \\
\hline & \multirow{2}{*}{$\begin{array}{l}\text { Filling } \\
\text { ability }\end{array}$} & $\begin{array}{l}\text { Slump } \\
\text { Flow }\end{array}$ & $\begin{array}{l}520-800 \\
\mathrm{~mm}\end{array}$ & 580 \\
\hline & & flow t-50 & $\begin{array}{l}2-5 \\
\text { second }\end{array}$ & 5 \\
\hline \multirow{4}{*}{$\begin{array}{l}\text { B022 } \\
\text { R1.8 }\end{array}$} & $\begin{array}{l}\text { Passing } \\
\text { ability }\end{array}$ & U-type & $0-30 \mathrm{~mm}$ & 30 \\
\hline & Viscosity & V-funnel & $\begin{array}{l}6-12 \\
\text { second }\end{array}$ & 12 \\
\hline & \multirow{2}{*}{$\begin{array}{l}\text { Filling } \\
\text { ability }\end{array}$} & $\begin{array}{l}\text { Slump } \\
\text { Flow }\end{array}$ & $\begin{array}{l}520-800 \\
\mathrm{~mm}\end{array}$ & 660 \\
\hline & & flow t-50 & $\begin{array}{l}2-5 \\
\text { second }\end{array}$ & 5 \\
\hline
\end{tabular}

Variation of absolute mortar volume coefficient value gave the different weight of coarse aggregate, the higher coefficient score, the lesser aggregate will be used. The design of the aggregate mixture with 36\%: $64 \%$ for fine and coarse aggregate comparison procedure and $\mathrm{w} / \mathrm{p}$ ratio of 1.21 has a $696.7 \mathrm{~mm}$ flow 
rate (Aggarawal, et al., 2008). In this study, a decrease in the number of coarse aggregates was used to provide increased SCC flow capability. However, the optimum value of coarse aggregate and the fine aggregate ratio at 57.21: 42.78 resulted in the flowability of $580 \mathrm{~mm}$ with $100 \mathrm{MPa}$ compressive strength. The mechanical properties of concrete can be seen in Table 7.

Uniform super plasticizer level at $1.6 \%$ value obtained from a maximum value of maximum mortar is a compressive strength.

Table 7. Mechanics properties of concrete

\begin{tabular}{llll}
\hline Code & Coefficient & $\begin{array}{l}f^{\prime}{ } \\
(\mathrm{MPa})\end{array}$ & $\begin{array}{l}\text { Value } \\
(\%)\end{array}$ \\
\hline B022R1.8 & 1.4 & 88.17 & $70.00: 30.00$ \\
B022R1.6 & 1.6 & 100.00 & $57.21: 42.78$ \\
B022R1.4 & 1.8 & 97.90 & $36.02: 63.97$ \\
\hline
\end{tabular}

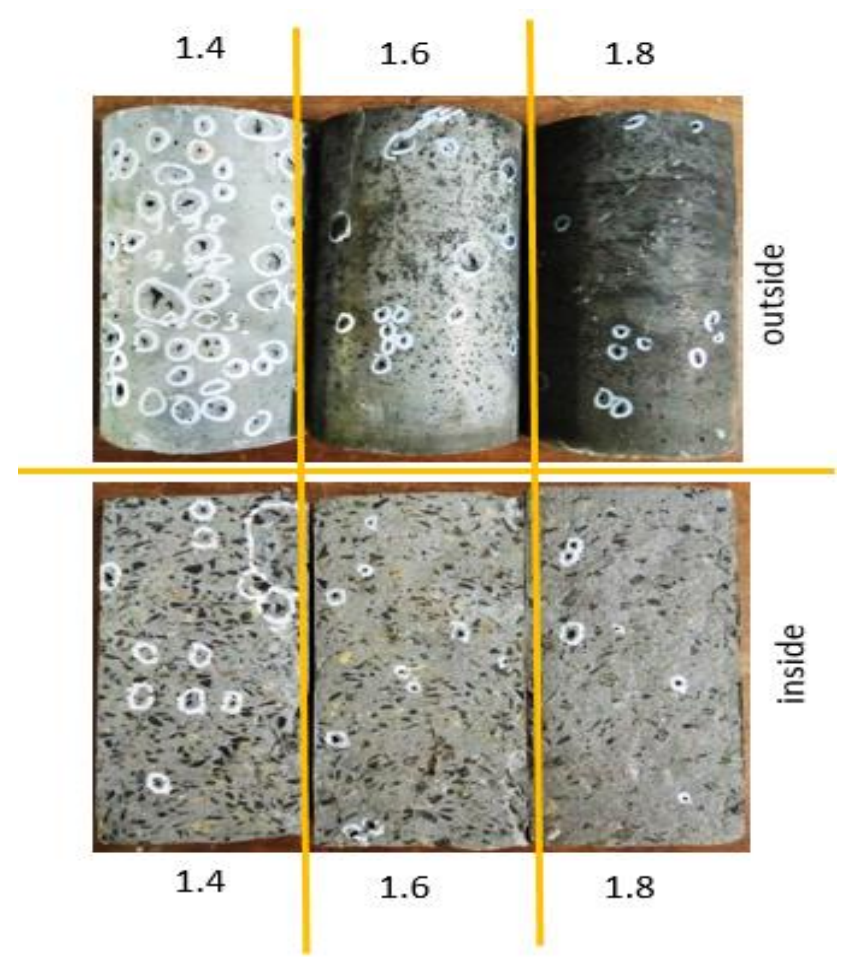

Figure 6. Air cavity on the specimen. in a variation of coefficient mortar absolute volume.

\section{CONCLUSIONS}

From the analysis result and discussion which were conducted, several things could be concluded, such as follows:

a) The design of mortar mixture had the highest compressive strength value with the addition of $1.6 \%$ superplasticizer, with a compressive strength value of $135.45 \mathrm{MPa}$, and a $250 \mathrm{~mm}$ flow. The increased dosage of superplasticizer provides improved workability of mortar.

b) The concrete mix design highest compressive strength at coefficient score 1.6. slump flow value was $580 \mathrm{~mm}$ and $100 \mathrm{Mpa}$ for Compressive strength.

c) The way of the two-stage design was easier to control and to predict the concrete flow conditions when designing SCC.

\section{ACKNOWLEDGMENT}

Thanks to Civil and Environmental Engineering Department, Universitas Gadjah Mada for the permission to work overnight in the Structural Laboratory and to the local government of Tangerang Regency for the provision of financial support until the master study was completed.

\section{REFERENCES}

Aggarawal, Raffat, S., Y, A. \& M, G., 2008. SelfCompacting Concrete - Prosedure for Mix Design. Journal of Practices and Technologies, pp. 15-24.

BSNI, Badan Standardisasi Nasional. (2000). "Tata Cara Pembuatan Rencana Campuran Beton Normal" (SNI 03-4804-1998). Jakarta: BSNI.

EFNARC, 2005. The European Guidelines for SelfCompacting Concrete Specification, Production and Use.

Fehling, E. \& Schmidt, M., 2010. Ultra High Performance Concrete. Kessel, s.n.

Houssan, A. \& Toutanji, T., 1995. The Influence of Silica Fume on The Compressive Strength of Cement Paste and Mortar. Journal of Cement and Concrete Research, 7(25), pp. 1591-1602.

Maten, R. N., 2011. Ultra High Performance Concrete In Large Span Shell Structure. Rotterdam: Zonneveld Ingenieurs.

Mazloom, Ramezanianpour \& Brooks, 2004. Effect of Silica Fume on Mechanical Properties of HighStrength Concrete. Journal of Cement and Concrete Composite, Issue 26, pp. 347-357.

Okamura, H. \& Ouchi, M., 2003. Self Compacting Concrete. Journal of Advanced Concrete Technology, $\mathrm{I}(1)$, pp. 5-15.

Rahul, D. \& Pardeep, K., 2013. Effect of Fly ash on Water/Powder Rtio and Superplasticizer Dosage in Self Compating Mortars. International Journal of Architecture, Engineering and Construction, Volume 2, pp. 55-62. 
Raju, N. K., 1983. Design of Concrete Mixes. New Delhi: Srinivasnagar.

Satyarno, I., 2014. Practical method for mix design of cement-based grout. 2nd International Conference on Sustainable Civil Engineering Structures and Construction Material.

Tue, N. V., Jianxin, M. \& Orgass, M., 2008. Influence of Additional Method of Superplasyicizer on The Properties of Fresh UHPC. International Symposium of UHPC, 7(25), pp. 93-100.
Widodo, S., 2004. Optimalisasi Kuat Tekan Self Compacting Concrete dengan Cara Trial Mix Komposisi Agregat dan Filler Pada Campuran Adukan Beton.

Yurdakul, E., 2013. Effect of Paste to Void Volume Ratio on The Performance of Concrete Mixture. Journal of Material in Civil Engineering, pp. 18401851. 